\title{
A Comparative Study on the New Version and the Old Version of Provisions for Value-added Tax Accounting Treatment
}

\author{
Rongjun Yang ${ }^{1, a}$ \\ ${ }^{1}$ College of Economics and Management, Zaozhuang University, China \\ a1667100164@qq.com
}

Keywords: Value-Added Tax, Accounting Treatment, Problems.

\begin{abstract}
December 2016, the Ministry of Finance issued a new version of Provisions for Value-added Tax Accounting Treatment. The provision makes specific regulation on accounting treatment for change from business tax to value-added tax, and improves the setting of accounting subjects. But there are some problems and mistakes which should be solved by relevant departments as soon as possible.
\end{abstract}

\section{Introduction}

In December 3, 2016, the Ministry of Finance issued the Provisions for Value-added Tax Accounting Treatment (No.22 Document issued by Department of Accounting of the Ministry of Finance in 2016), hereinafter referred to as the official version. Compared with the exposure draft released in July 2016, the official version has made obvious adjustment in the setting of accounting subjects and columns, and the items presented in financial statements. But there are some problems and mistakes in the provision. This article mainly analyzes and studies these regulations.

Significant Adjustment in Accounting Subjects Setting. Four grade two subjects are added, including "VAT (Value-added Tax) credits" "tax on simple and easy method" "value-added tax from transferring financial products" and "withhold and remit VAT". There are still 10 grade three subjects under "value added tax payable". Calculation, drawing, deduction and transfer for general taxpayers are treated according to the 10 grade three subjects under "value added tax payable". Tax accounting has more clarity. (2) "Tax on simple and easy method" changes from a grade three subject to grade two subject. Compared with the draft, the official version upgrades the item to grade two subject. Calculation, drawing, deduction and transfer for general taxpayers on simple and easy method are treated differently from general method. Tax accounting has more clarity. (3) "Value-added tax paid after service" changes to "VAT pay in advance". The official version takes into account of construction and real estate enterprises which have long development cycle. The time spans between tax pay in advance and actual tax obligations are large. A grade two accounting subject is made to deal with these cases. It agrees with the provisions of tax laws, and provides convenience for the final treatment which needs different kinds of value-added tax reported separately. (4) The subject "export deduct domestic sales goods tax" is restored. (5) Small scale taxpayers also need to set up subjects on "value-added tax from transferring financial products" and "withhold and remit VAT". But it should be noted that, during the period of changing business tax to value-added tax, VAT on interests from financial goods is not accounted according to this subject, but to the subject of "tax payable - VAT on sales". (5) The provision changes the grade one subject "business tax and additional" to "tax and additional". Property tax, land use tax, vehicle and vessel use tax and stamp tax are no longer included in administrative expenses, but included in the "tax and additional". "Business tax and additional" in profit statement is also adjusted to "tax and additional". The adjustment adapts to the latest development of accounting processing business, and makes up for the deficiencies of original accounts. Accounting treatment is more clear, while accounting content is more reasonable. 


\section{Obvious Changes in Accounting Treatment}

Different accounting treatments in obtaining the VAT special invoice. authenticated and non-authenticated. General taxpayers need to obtain VAT special invoices (hereinafter referred to as the special invoices). If the invoice is authenticated, debit: "tax payable - VAT payable"; if not, debit: "tax payable - VAT to be authenticated", credit: "bank deposit" and other subjects.

For example: in January 2017, a company bought some raw materials, and obtained value-added tax invoices showing the price as 100 thousand, value-added tax 17 thousand. Payment for goods is not paid.

If the invoice is authenticated, accounting treatment goes: debit: raw material 10, tax payable VAT payable (input VAT) 1.7, credit: account payable 11.7

If the invoice will be authenticated next month, accounting treatment goes: goods purchased in January, debit: raw materials 10 , tax payable - VAT to be authenticated 1.7 , credit: account payable 11.7

In February, after the authentication of invoice: debit: tax payable - VAT payable (input VAT) 1.7, credit: tax payable- VAT to be authenticated 1.7

If the goods are returned, authenticated and non-authenticated invoices are treated differently. If the invoice is authenticated, accounting entries to the contrary shall be made according to the red special note issued by tax authority; if the invoice is not authenticated, accounting entries to the contrary shall be made, and the invoice should be returned.

For example: assuming all the goods in the above example are returned in February.

If the invoice has been authenticated, the company should go to tax authority to apply for red special note, accounting treatment goes: debit: raw materials -10, tax payable - VAT payable (input VAT) -1.7, credit: account payable -11.7

If the invoice is not authenticated, the buyer should return the invoice; the accounting treatment goes: debit: raw materials -10, tax payable - VAT payable (input VAT) -1.7, credit: account payable $-11.7$

Non-creditable input tax should also be checked according to the subject of "tax payableinput VAT to be authenticated". After the general taxpayer obtaining special invoice, non-creditable input tax should be debited as "tax payable - VAT to be authenticated", credited as "bank deposit" or other subjects. After the tax authority authenticated, related costs and asset accounts should be debited, credit "tax payable - VAT payable (transfer out unpaid VAT)". This provision has completely changed the general processing methods of enterprises.

For example: in January 2017, a company purchased an equipment for VAT exempt items, and obtained special invoice indicating the price was 100 thousand, value-added tax was 17 thousand. The equipment has been paid.

When purchasing equipment and obtaining invoices, debit: fixed assets 10, tax payable - VAT to be authenticated 1.7, credit: bank deposit 11.7

After authentication, debit: fixed asset 1.7, credit: tax payable - VAT payable (transfer out unpaid VAT) 1.7

Accounting treatment on "confirming tax obligation" and "confirming accounting income" happen at different time. If tax obligation confirmation is earlier than accounting income confirming, debit "tax payable - VAT payable (output VAT)" or "tax payable - payable VAT (tax on simple and easy method)". Then the income is confirmed according to amount deducted from output VAT. It helps enterprises to separate price from tax, and learn their payable tax in the future more clearly.

For example: at the beginning of January 2017, a company rent a real estate (tax on simple and easy method), and received rent for a year: 1 million 50 thousand yuan. The special invoice is made.

Accounting treatment goes as following. debit: bank loan 105; credit: deposit received 100, tax payable - VAT payable (tax on simple and easy method) 5

Income confirmed in the future, debit: deposit received 100, credit: other business income 100 
If tax obligation confirmation is later than accounting income confirming, debit "tax payable - stay recognition tax". When paying tax, debit "tax payable - VAT payable (output VAT)" or "tax payable - payable VAT (tax on simple and easy method)".

For example, in January 2017, a company acquired a certain amount of bonds and held to maturity. The bond value was 10 million yuan. After 3 years, capital will be repaid with interests; the coupon rate was $10 \%$.

When buying bonds in early 2017, debit: held to maturity investment - cost 1000, credit: bank deposit 1000

Interest is paid at the end of each year from 2017 to 2019 .

debit: held to maturity investment - accrued interest 100, credit: investment income 94.34 (100/1.06), tax payable - stay recognition tax $5.66(100 * 6 \% / 1.06)$

At the end of 2019, capital repaid with interests. Debit: bank deposit 1000, credit: held to maturity investment - cost

debit: tax payable - stay recognition tax 283.02

credit: tax payable - payable VAT (output tax) 283.02

Latest provisions on the treatment of unpaid business tax for recognized income after Change from Business Tax to Value-Added Tax. If an enterprise has confirmed the income but not calculated business tax, VAT should be calculated, and the current income should be offset. If the company has calculated business tax but not paid, the accounting treatment goes as following. Debit: "tax payable - business tax payable", credit: "tax and additional", then debit: "main business income", credit: "tax payable - VAT on sale".

For example: a company got income of 1 million yuan before the change, the business tax rate was $5 \%$. After the change, the value-added tax rate was also $5 \%$.

If an enterprise has calculated business tax but not paid, the accounting treatment goes:

business tax before the change, debit: business tax and additional 5, credits: tax payable - business $\operatorname{tax}$

After the change, debit: tax payable - business tax 5, credits: tax and additional 5

debit: the main business income of 4.76 , credit: tax payable - VAT on sales $4.76(100 * 5 \% / 1.05)$

If the enterprise do not need to pay the business tax, the accounting treatment goes:

debit: the main business income 4.76, credit: tax payable - VAT payable 4.76 (VAT on sales)

New regulations on transferring financial products value-added tax. Financial commodities transferring tax is made according to the difference between profits and losses. If the company makes profits, "investment income" and other subjects should be debited according to the amount of tax, credit: "tax payable - transferring financial goods VAT payable". If the company makes losses, the tax deduction can be carried forward to next month, debit: "tax payable - transferring financial goods VAT payable", credit: "investment income" and other subjects. When paying value-added tax, debit: "tax payable - transferring financial goods VAT payable", credit: "bank deposit". At the end of the year, if there's surplus, debit: "investment income" and other subjects, credit: "tax payable transferring financial goods VAT payable". Compared with the draft, the official version made significant changes. The draft requires treatment through "tax payable - VAT payable"; the official version regard VAT payable as "investment income" which can be deducted, and debit "investment income". When losses occur, taxes are deducted as income, and credit "investment income". From the perspective of tax declaration, the draft is more reasonable. Regulations in the official version make this part of tax difficult to fill in to the VAT declaration form for general taxpayers.

For example: in January 2017, A company purchased 1 million shares of B company's stocks. The purchase price was 10 yuan per share (including 1 yuan of fees). A company treated these stocks as trading financial assets.

When buying stock, debit: transaction financial assets - cost 900, investment income 100, credits: bank deposit 1000

If A company transfers these shares at the end of the month, and the transfer price is 15 yuan (after deducting fees, taxes, etc.)

Financial products transferring value added tax $=(1500-900) / 1.06 * 6 \%=5.66$ 
debit: bank deposit 1500, credits: trading financial assets - cost 900, investment income 600

Debit: investment income 5.66, credits: payable tax - financial products transferring value added $\operatorname{tax} 5.66$

Actual value-added tax: tax payable - financial products transferring value added tax 5.66

Credit: bank deposit 5.66

If the company will transfer these stocks in the future, and the transfer price will be 8 yuan (after deducting fees, taxes, etc.)

Debit: bank deposit 800, investment income 100, credits: trading financial assets - costs 900

Debit: tax payable - financial products transferring value added tax 5.66, credit: investment income 5.66

\section{Existing Problems in the Official Version}

Unreasonable treatment on loss carry forward of financial products. The draft stipulates that if the financial commodity transfers but losses occurs, the tax deduction can be carried forward next month. But whether the current earnings can be carried forward to offset the losses? Does the losses at the end of the year can be carried forward to the next year? The answer is negative in accordance with original provisions. This means that, if an enterprise makes profit of 1 million yuan in the first half of the year by transferring financial products, but has 1 million losses at the second half, the company need to pay VAT $100 * 6 \% /(1+6 \%)=5.66$ million. But if another enterprise losses 1 million in the first half, and makes profits at the second half, the company do no need to pay VAT. It is not reasonable and will lead enterprise to tax evasion. The author suggests that relevant departments to consider the offset problem, and allow profit to be carried forward to the next term.

Non-creditable input taxes on purchasing and other businesses contradict with accounting standard. The Ministry of Finance issued the No. 4 Standards for Enterprises Accounting - Fixed Assets, and clearly stipulated that, non-deductible input VAT should be included in the original value of fixed assets. The official version does not conform to these accounting standards. The value of fixed assets in the first year will be different from that of second years. At the same time, due to the existence of cross-year problem, loss adjustment of the previous year should also be dealt with. The process is more complex. Thus, the official version stipulates, if the income tax can not be deducted, debit: "tax payable - VAT to be authenticated", credit: "bank deposit" and other subjects. After the tax authority's authentication, debit: related costs or asset accounts, credit "tax payable - VAT payable (transfer out of input tax)". According to this treatment, "tax payable - VAT to be authenticated" remains. We suggest that the following steps should be added. After the tax authority's authentication, debit: tax payable - VAT payable (input VAT), credit: tax payable - VAT to be authenticated. Then the input tax to be authentication will be balanced.

The official version stipulates, the non-deductible input tax which has been included in the tax to be authenticated, should be directly transferred to payable input tax, and be included in the relevant asset or expense account. The treatment can lead to retention of special invoices. Suggestions go as the following.

(1) debit: tax payable - VAT payable (input VAT), credit: tax payable - input VAT to be authenticated (2) debit: fixed asset and others, credit: tax payable - VAT payable (transfer out of input tax). This will ensure the balance between tax payable and payable VAT to be authenticated.

With the carrying forward of Change from Business Tax to Value-Added Tax, enterprises will have increasing VAT accounting problems. The Ministry of Finance issued a new version of value-added tax provisions, which is of important significance to standardize the accounting treatment of VAT. But this provision has some shortcomings and mistakes, and we hope relevant departments can solve them as soon as possible. 


\section{References}

[1] Ministry of Finance, Provisions for Value-added Tax Accounting Treatment (No.22 Document issued by Department of Accounting of the Ministry of Finance in 2016).

[2] Ministry of Finance, Provisions for Value-added Tax Accounting Treatment (Exposure Draft) (No.27 Document issued by Office of the Ministry of Finance in 2016).

[3] Ministry of Finance, Provisions of Enterprise Accounting Treatment on the Trial Operation of Changing Business Tax to Value-Added Tax (No.13 Document issued by Department of Accounting of the Ministry of Finance in 2016). 